Protecting Children from Sexual Violence in Armed Conflict under International Humanitarian Law : Discrepancies between Conventions and Practice of International Criminal Courts and Tribunals

\author{
Almila, Elina
}

2019-11-23

Almila , E 2019 , ' Protecting Children from Sexual Violence in Armed Conflict under International Humanitarian Law : Discrepancies between Conventions and Practice of International Criminal Courts and Tribunals ' , Journal of International Humanitarian Legal Studies , vol. 10 , no. 2 , pp. 217-239 . https://doi.org/10.1163/18781527-01002008

http://hdl.handle.net/10138/321793

https://doi.org/10.1163/18781527-01002008

unspecified

acceptedVersion

Downloaded from Helda, University of Helsinki institutional repository.

This is an electronic reprint of the original article.

This reprint may differ from the original in pagination and typographic detail.

Please cite the original version. 


\title{
Protecting Children from Sexual Violence in Armed Conflict under International Humanitarian Law
}

\section{Discrepancies Between Conventions and Practice of International Criminal Courts and Tribunals}

\author{
Elina Almila \\ Phd Candidate \\ University of Helsinki, Helsinki \\ elina.almila@helsinki.fi
}

\begin{abstract}
Children enjoy special protection from the harms of armed conflict under international humanitarian law. While the protection of children in armed conflict has been widely researched with regard to recruitment and use of children in armed conflict, the research on protection of children from sexual violence has received less attention. In this paper I look at the protection of children in relation to sexual violence under international humanitarian law and its actualisation in the practise of international criminal courts and tribunals. I consider first how the protection of children from sexual violence under international humanitarian law made its way to Conventions. Second, I explore the case law of sexual violence as a war crime in international courts and tribunals and how the special protection of children is reflected in the case law. I argue that despite a gradual improvement, the provisions of the Conventions have not been recognised particularly well. While there have been cases in which more attention has been paid to sexual violence against children, the practice is mostly incoherent and sporadic: there exists a discrepancy between the Conventions, and the practice of international criminal courts and tribunals.
\end{abstract}

Keywords: Children in armed conflict, sexual violence against children, protection of children, international humanitarian law, international criminal courts and tribunals.

\section{Introduction}

Sexual violence against children in armed conflict has been topical over the past years. Rape, sexual slavery and other forms of sexual violence against children in armed conflict has been reported around the world. ${ }^{1}$ Since the International Criminal Court ('ICC') started its work in 2002, the international

\footnotetext{
${ }^{1}$ See, for example Human Rights Watch, 'Iraq: ISIS Escapees Describe Systematic Rape' (Human Rights Watch 2015) <www.hrw.org/news/2015/04/14/iraq-isis-escapees-describe-systematic-rape>; UNGA 'Report of the Secretary-General on Children and Armed Conflict' (16 May 2018) UN Doc A/72/865.
} 
legal community has followed several proceedings in cases involving sexual violence against children. Most recently, the Ntaganda case has drawn attention to the issue as it has dealt with sexual violence committed against both civilian children and child soldiers. ${ }^{2}$ Children enjoy special protection from the harms of armed conflict under international humanitarian law and the protection of children has been widely researched with regard to the recruitment and use of children in armed conflict. What has been less researched, despite the high level of its occurrence, is the protection of children from sexual violence in armed conflict. ${ }^{3}$ There is no doubt about the reprehensibility of the crime. Violence against children has been described as one of the deepest depths humanity can sink to $^{4}$ and the United Nations has defined sexual violence in armed conflict as one of the "six grave violations against children." 5

The special protection from sexual violence under international humanitarian law is well-established. For instance, the Office of the Prosecutor of the ICC has noted that because of the 'special recognition and protection of children under international law' it will regard crimes against children as 'particularly grave'. ${ }^{6}$ Indeed, sexual violence as war crime is also well-established today. But how well is the conventional protection under international humanitarian law reflected in the case law of international courts and tribunals? It is my main contention, and the main argument of this paper, that despite the gradual improvement, there remains a clear discrepancy in practice: while the courts and tribunals sometimes recognise the protection of children as a particular issue, most often sexual violence against children gets lost in the mass of crimes. Yet, the claimed aim of the international criminal courts and tribunals is not only to punish for crimes, but also to prevent them. ${ }^{7}$ If sexual violence against children continues to get lost in the mass of crimes, there is a risk that these crimes will not be acknowledged, and in turn have no preventative effect. Further, while sexual violence can also be prosecuted as a crime against humanity, as this paper considers the relationship between international humanitarian law and the practice of international courts and tribunals, I have limited the discussion to war crimes.

\footnotetext{
${ }^{2}$ The Prosecutor v Bosco Ntaganda (Judgment) ICC-01/04-02/06 (8 July 2019).

${ }^{3}$ It should be noted that these crimes often overlap, as child soldiers are also victims of sexual violence.

${ }^{4}$ UNGA 'Impact of Armed Conflict on Children, Report of the Expert of the Secretary-General Ms Graça Machel submitted pursuant to the General Assembly Resolution 48/157' (26 August 1996) 51st Session UN Doc A/51/306 ('Machel Report') [3].

${ }^{5}$ Office of the Special Representative of the Secretary General for Children and Armed Conflict, 'The Six Grave Violations Against Children During Armed Conflict: The Legal Foundation' (October 2009) Working Paper No 1 $<$ https://childrenandarmedconflict.un.org/publications/WorkingPaper-1_SixGraveViolationsLegalFoundation.pdf >. ${ }^{6}$ International Criminal Court ('ICC'), 'Policy on Children' (ICC, 15 November 2016) < https://www.icccpi.int/iccdocs/otp/20161115_OTP_ICC_Policy-on-Children_Eng.PDF> 26.

${ }^{7}$ See, for example, The ICC's current 'Humanity against crimes' campaign emphasising the purpose to prevent crimes. (ICC) <www.icc-cpi.int/humanity-against-crimes/pages/striving-to-prevent-crimes.aspx> accessed 14 September 2019.
} 
The paper is built as follows: first, I will reflect upon the sexual violence against children in armed conflict as a phenomenon, and the prevalence and consequences thereof. Second, I will explore the protection of children in armed conflict in general and with regard to sexual violence in particular. Third, I will examine sexual violence against children as a war crime and the related case law of international criminal courts and tribunals. I draw my conclusions from the case law of the International Criminal Tribunal for the Former Yugoslavia (ICTY), the International Criminal Tribunal for Rwanda (ICTR), the Special Court for Sierra Leone (SCSL) and the ICC, since all of these institutions have dealt with situations that were notorious for sexual violence, including that perpetrated against children. Finally, I will bring together the written law enshrined in conventions and the practice of the courts and tribunals to consider how well they meet.

Before moving on, a small note on some key definitions. International humanitarian law does not explicitly define what is the age-limit for 'a child'. ${ }^{8}$ For the purposes of this paper, I use as the definition for 'a child' consistent with the definition prescribed by the United Nations Convention on the Rights of the Child. Therefore, 'a child' for the purposes of this paper means 'every human being below the age of eighteen years unless under the law applicable to the child, majority is attained earlier.' 9 This approach is also adopted by the Office of the Prosecutor of the ICC, which considers the age-limit for a child to be $18 .{ }^{10}$ I will also use the term 'victim' in this paper. While there is a discussion as to whether we should discuss victims or survivors of sexual violence, ${ }^{11}$ I have chosen to use the term 'victim' to include those who did not survive the attack.

\section{Sexual Violence Against Children in Armed Conflict}

Sexual violence in armed conflict has been defined as 'any act of a sexual nature which is committed on a person under circumstances which are coercive ${ }^{12}$ and is hence broader crime than only rape. ${ }^{13}$ Today, sexual violence in armed conflict is understood to include rape, sexual slavery, enforced

\footnotetext{
${ }^{8}$ See, for example, Protocol Additional (I) to the Geneva Conventions of 12 August 1949, and relating to the Protection of Victims of International Armed Conflicts (adopted 8 June 1977, entered into force 7 December 1978) 1125 UNTS 3 ('AP I') art 77(2); Protocol Additional (II) to the Geneva Conventions of 12 August 1949, and relating to the Protection of Victims of Non-International Armed Conflicts (adopted 8 June 1977, entered into force 7 December 1978) 1125 UNTS 609 ('AP II') art 4(3)(c). The Commentary to the API notes that not defining a specific age for a child was intentional, even if the age of fifteen 'seems to provide a reasonable basis for a definition'. Claude Pilloud and others (eds), Commentary on the Additional Protocols (International Committee of the Red Cross 1987) 898. Many do not consider, however, that this means a fixed age-limit. See, example, Hans-Peter Gasser, 'Protection of the Civilian Population' in Dieter Fleck (ed), The Handbook of International Humanitarian Law (Oxford University Press, 2nd edn, 2008$) 245$.

${ }^{9}$ Convention on the Rights of a Child (adopted 20 November 1989, entered into force 2 September 1990) 1577 UNTS 3 ('CRC') art 1.

${ }^{10} \mathrm{ICC}$ (n 6) 11.

${ }^{11}$ See, for example, Anne-Marie de Brouwer, 'What the International Criminal Court has Achieved and Can Achieve for Victims/Survivors of Sexual Violence’ [2009] 16 International Review of Victimology 183, 184.

${ }^{12}$ Prosecutor v Akayesu (Judgment) ICTR-96-4-T, T Ch I (2 September 1998) [688].

${ }^{13}$ Prosecutor v Kvočka et al (Judgment) ICTY-98-30/1-T, (2 November 2001) [180].
} 
prostitution, forced pregnancy, enforced sterilisation, and any other form of sexual violence of comparable gravity. ${ }^{14}$

Children face a number of risks during armed conflict including that of direct violence. Risks for children grow if they are separated from their parents, have to leave their home, are recruited to armed forces or are detained. ${ }^{15}$ All of these situations also increase the risk of sexual violence. While sexual violence is most often associated with girls, ${ }^{16}$ both girls and boys are at risk of becoming victims. Children do not become targets of warfare just as part of civilian population, but also specifically as children. The violence against children may be aimed to destroy the future of the enemy in ethnic conflict as well as to suppress the whole civilian population. ${ }^{17}$ The consequences of sexual violence in armed conflict are serious, and research shows that sexual violence may lead to physical and mental damage, as well as to 'humiliation, degradation [and] subordination. ${ }^{18}$ Survivors may suffer from sexually transmitted diseases, including HIV/AIDS ${ }^{19}$ and rape can also lead to unwanted pregnancy and giving birth to the rapist's child for girls ${ }^{20}$ or to the 'taint of homosexuality' for boys. ${ }^{21}$ Child victims face long-term consequences that affect such fundamental things, such as the way their personal values and political beliefs are constituted, how their identity is built and what kind of role in society the child will have as an adult. ${ }^{22}$ These consequences may have immeasurable impact on the future of the whole society. According to experts, the mass traumatisation of children may affect the stability of the society in the future, as well as the maintenance of peace. ${ }^{23}$ As victims of sexual violence, children may face long-term socio-economic challenges, as sexual exploitation tends to continue after the war has ended. Children may also be rejected by their families. Child victims of sexual violence may also have problems of marrying or they might end up in prostitution. ${ }^{24}$

Reports of sexual violence against civilian children in armed conflict are sadly common. ${ }^{25}$ In 2016 the United Nations reported hundreds of cases of sexual violence against children that were conducted

\footnotetext{
${ }^{14}$ Rome Statute of the International Criminal Court (adopted 17 July 1998, entered into force 1 July 2002) 2187 UNTS 90 ('Rome Statute') arts 7(1)(g); 8(2)(b)(xxii); 8(2)(e)(vi).

15 UNICEF Innocenti Research Centre, 'International Criminal Justice and Children' (No Peace Without Justice, September 2002) 30.

16 ibid.

17 ibid.

${ }^{18}$ Kelly Dawn Askin, War Crimes Against Women (Martinus Nijhoff Publishers 1997) 16.

${ }^{19}$ UNICEF Innocenti Research Centre (n 15) 80.

${ }^{20}$ See, for example, Prosecutor $v$ Sesay, Kallon and Gbao (Judgement) SCSL-04-15-T-1251 (2 March 2009) ('RUF Trial Judgment') [1520].

${ }^{21}$ Sandesh Sivakumaran, 'Male/Male Rape and the "Taint” of Homosexuality' [2007] 27 HRQ 1274.

${ }^{22}$ UNICEF Innocenti Research Centre (n 15) 31.

23 ibid 31.

${ }^{24}$ ibid 80.

${ }^{25}$ See, for example, Human Rights Watch, 'Shattered Lives. Sexual Violence During Rwandan Genocide and Its Aftermath' (Human Rights Watch, September 1996)
} 
by armed groups, militias and government armed forces in the Democratic Republic of Congo, Somalia and South Sudan, ${ }^{26}$ where '[b]oys were reportedly castrated and sexually mutilated, while girls who resisted rape were killed.' ${ }^{27}$ In Syria, civilian children have been raped, and even gangraped. ${ }^{28}$ Children are forced to sexual slavery during armed conflict and young girls are forced to live as 'wives' of soldiers. ${ }^{29}$ Children are also exposed to sexual violence when they join armed forces or groups. After the civil war in Sierra Leone, a significant number of girl and boy soldiers reported having been raped ${ }^{30}$ and girl soldiers have been forced to provide sexual services for their fellow soldiers. $^{31}$

Sexual violence against child soldiers is also a form of sexual violence against children in armed conflict that has received relatively considerable attention from both international courts and tribunals, as can be seen below, and from academics. ${ }^{32}$ Detained children also face a heightened risk of sexual violence. In the former Yugoslavia, young girls were kept in so-called rape camps to be raped for long periods of time, sometimes with the aim of forcibly impregnating them. ${ }^{33}$ In Syria, fighting-age boys have been detained and sexual violence has been used against them as interrogation method. ${ }^{34}$ There is no general data available for estimating the prevalence of this problem. However, due to the stigma that still surrounds sexual crimes, as well as the fact that these are crimes that do

\footnotetext{
<https://www.hrw.org/sites/default/files/reports/1996_Rwanda_\%20Shattered\%20Lives.pdf>; Report of the SecretaryGeneral, 'Children and Armed Conflict' (2016) UN Doc A/70/836-S/2016/360 [35], [37]; Report of the Independent International Commission of Inquiry on the Syrian Arab Republic (2013) UN Doc A/HRC/22/59 [104]-[111]; Save the Children, 'Unspeakable Crimes Against Children: Sexual Violence in Conflict' (Save the Children, 2013) <https://www.savethechildren.es/sites/default/files/imce/docs/unspeakable_crimes_report.pdf >; Maria Sliwa, 'Sudan Cries Rape' (WorldNetDaily, 2 March 2004) < http://www.wnd.com/ 2004/03/23542/>; Report of the International Commission of Inquiry on Libya (2014) UN Doc A/HRC/19/68 [65]-[70].

${ }^{26}$ Report of the Secretary-General (n 25) [48], [166], [125].

27 ibid [125].

${ }^{28}$ Report of the Independent International Commission of Inquiry on the Syrian Arab Republic (15 August 2012) UN Doc A/HRC/21/50, Annex IX [7].

${ }^{29}$ With regard to examples from Syria, see, example, Human Rights Council, "“They came to destroy": ISIS Crimes Against the Yazidis' (15 June 2016) UN Doc A/HRC/32/CRP.2 [42]-[80]; With regard to examples from Rwanda, see, example Prosecutor v Édouard Karemera and Matthieu Ngirumpatse (Judgment) ICTR-98-44-T (2 February 2012); With regard to examples from Sierra Leone, see, example RUF Trial Judgment (n 20); Prosecutor v Brima, Kamara and Kanu, (Judgment) SCSL-04-16-T (20 June 2007) ('AFRC Trial Judgment'); Prosecutor v Charles Ghankay Taylor (Judgment) SCSL-03-01-T-1283 (18 May 2012).

${ }^{30}$ Theresa Betancourt and others, 'Sierra Leone's Child Soldiers: War Exposures and Mental Health Problems by Gender' [2011] 49 J Adolesc Health 21-28.

${ }^{31}$ Machel Report (n 4) [45]-[46]; Report of the Secretary-General (n 25) [35].

${ }^{32}$ See, for example Tilman Rodenhäuser, 'Squaring the Circle?: Prosecuting Sexual Violence against Child Soldiers by their "Own Forces", [2016] 14 Journal of International Criminal Justice 171; Rosemary Grey, 'Sexual Violence against Child Soldiers: The Limits and Potential of International Criminal Law' [2014] 16 International Feminist Journal of Politics 602.

${ }^{33}$ See, for example, Cherif Bassiouni and others, Sexual Violence. An Invisible Weapon of War in the Former Yugoslavia (International Human Rights Law Institute 1996) 18.

${ }^{34}$ See, for example, Report of the Independent International Commission of Inquiry on the Syrian Arab Republic (2012) UN Doc A/HRC/21/50 [73], [107].
} 
not necessarily leave any physical evidence behind, it is likely that sexual violence against children in armed conflict is seriously underreported.

\section{Protection of Children in Times of Armed Conflict}

\subsection{International Law and Children in Armed Conflict}

The image of children in need of special protection has existed in international law for hundreds of years. International lawyers and legal thinkers from Alberico Gentili ${ }^{35}$ to Emer de Vattel $^{36}$ have written of innocent children against whom no force or violence should be used. In the mid-19 ${ }^{\text {th }}$ century the Lieber Code - drafted to regulate the warfare in the Civil War of the United States but seen to codify the customary law of armed conflict of its time - noted that children along with women should be removed from areas of bombardment. ${ }^{37}$ By the early $20^{\text {th }}$ century the first Declaration on the Rights of the Child noted that children should receive preferential treatment with regard to relief in times of distress. ${ }^{38}$ Today, international instruments have been created to protect children ${ }^{39}$ and international organisations and NGOs regularly call for protection of children from violence, including sexual violence, in times of armed conflict. ${ }^{40}$ National criminal codes in numerous countries, for their part, often include sexual violence against children as a separate crime or as an aggravating factor. ${ }^{41}$

In a similar manner, contemporary international humanitarian law includes several provisions on the protection of children. For instance, the Fourth Geneva Convention of 1949 refers to relief and support, education, exercise of religion, identification of children and treatment of detained minors. ${ }^{42}$ Children are also protected indirectly through their mothers, as pregnant mothers or mothers of small children shall also receive preferential treatment. ${ }^{43}$ Similar provisions are included in the First

\footnotetext{
${ }^{35}$ Alberico Gentili, De Iure Belli Libri Tres (Clarendon Press 1933) 257.

${ }^{36}$ Emer de Vattel, The Law of Nations (Fund Inc 2008) 549.

${ }^{37}$ Instructions for the Government of the United States in the Field by Order of the Secretary of War ('Lieber Code'), art 19.

${ }^{38}$ Geneva Declaration on the Rights of the Child (26 September 1924) League of Nations OJ Spec Supp 21 [3].

${ }^{39}$ CRC (n 9); African Charter on the Rights and Welfare of the Child (adopted 11 July 1990, entered into force 29 November 1999) CAB/LEG/24.9/49, Preamble.

${ }^{40}$ See, for example, UNSC Res 1261 (30 August 1999); UNGA Res 54/148 (25 February 2000); UNGA Res 54/149 (25 February 2000); Machel Report (n 4); Save the Children (n 25).

${ }^{41}$ See, for example, Criminal Law of the People's Republic of China 1979, art 236; Code Penal Congolais, Decret du 30 Janvier 1940, Mis à jour au 30 Novembre 2004, Titre IV, art 168; Central African Republic, Loi $N^{\circ} 10.001$ Portant Code Pénal Centrafricain 2010, art 87; England and Wales, Sexual Offences Act 2003, s 5 - 7; The Criminal Code of Finland, s 2(3); 5; 6; 7(2)(a); The Spanish Criminal Code Código Penal Español, arts 178-9; 183; The Criminal Code of Russian Federation NO. 63-FZ OF JUNE 13, 1996, (ed. 07.03.2017), art 131; Rwanda, Organic Law Instituting The Penal Code, $\mathrm{N}^{\circ}$ 01/2012/OL of 02/05/2012, arts 191-2; 197.

${ }^{42}$ Geneva Convention (IV) relative to the Protection of Civilian Persons in Time of War of 12 August 1949, (adopted 12 August 1949, entered into force 21 October 1950) 75 UNTS 287 ('GC IV') arts 23-24, 38, 50, 76, 89. With regard to detained children, see also Geneva Convention (III) relative to the Treatment of Prisoners of War of 12 August 1949 (adopted 12 August 1949, entered into force 21 October 1950) 75 UNTS 135 ('GC III') art 16 referring to privileged treatment on the basis of age.

${ }^{43}$ GCIV (n 42) arts $23,89$.
} 
Additional Protocol in $1977,{ }^{44}$ but at the time the protection of children was also extended by adding the prohibition of recruitment of children under the age of 15 years to armed forces and groups. ${ }^{45}$ The drafting of the Additional Protocols also brought about the special protection of children from sexual violence in armed conflict, to which I will turn to next.

\subsection{International Humanitarian Law and Sexual Violence Against Children}

Historically sexual violence was often seen as an inevitable part of armed conflict ${ }^{46}$ even if there were indications for its prohibition in some military codes and writings. ${ }^{47}$ References to its prohibition started to appear as early as in the $19^{\text {th }}$ century. ${ }^{48}$ In 1863 the above-mentioned Lieber Code included a paragraph that noted 'all rape ... [is] prohibited under the penalty of death.' ${ }^{49}$ This, together with other similar national instructions for militaries, have been relied upon to indicate that, at that time, rape was prohibited under customary international law. ${ }^{50}$ Notwithstanding, it was not until the early $20^{\text {th }}$ century before protection from sexual violence was mentioned for the first time in treaties. The 1929 Geneva Convention relative to the Treatment of Prisoners of War noted that ' $[w]$ omen shall be treated with all consideration due to their sex'. ${ }^{51}$ The wording of this provision was later repeated in the Geneva Conventions of 1949. ${ }^{52}$ This clause has been interpreted to include protection from sexual violence. ${ }^{53}$ The Fourth Geneva Convention of 1949, relative to the protection of civilian persons in times of war, refers directly to protection from sexual violence, including rape, enforced prostitution and any other form of "indecent assault. ${ }^{54}$ Early notions on sexual violence were related to the protection of women and as mentioned above. It was not until 1977 before the specific issue of sexual violence against children was included in international conventions.

\footnotetext{
${ }^{44}$ AP I (n 8) art 77(1).

${ }^{45}$ AP I (n 8) art 77(2); AP II (n 8) art 4(3)(c).

${ }^{46}$ See, example, Kelly Askin, 'Treatment of Sexual Violence in Armed Conflicts: A Historical Perspective and the Way Forward' in Anne-Marie de Brouwer et al (eds), Sexual Violence as an International Crime: Interdisciplinary Approaches (Intersentia 2013) 21-25.

${ }^{47}$ Gentili (n 35) 258; Theodor Meron, 'Rape as a Crime under International Humanitarian Law' 87 AJIL [1993] $424,425$.

${ }^{48}$ For an extensive consideration of the history of sexual violence in armed conflicts and international law, see especially Askin (n 18); Meron, (n 47).

${ }^{49}$ Lieber Code (n 37) art 44.

${ }^{50}$ Askin (n 48) 26.

${ }^{51}$ Geneva Convention Relative to the Treatment of Prisoners of War (adopted 27 July 1929, entered into force 19 June 1931) 75 UNTS 135 art 3.

${ }^{52}$ Geneva Convention (I) for the Amelioration of the Condition of the Wounded and Sick in Armed Forces in the Field of 12 August 1949 (adopted 12 August 1949, entered into force 21 October 1950) 75 UNTS 31 ('GC I') art 12; GC III, (n 41) art 14.

${ }^{53}$ Jean Pictet (ed), Commentary on the Geneva Conventions of 12 August 1949 Vol 3: Geneva Convention Relative to the Treatment of Prisoners of War (ICRC 1960) 147.

${ }^{54}$ GC IV (n 42) art 27.
} 
Sexual violence against children was added to the Additional Protocols of $1977 .{ }^{55}$ The First Additional Protocol reads that '[c]hildren ... shall be protected against any form of indecent assault', 56 which is interpreted to mean sexual assaults. ${ }^{57}$ This was at the time seen as 'a welcome supplement ... as experience has shown that children, even the very youngest children, are not immune from sexual assault. ${ }^{58}$ What is particular with regard to the protection of children from sexual violence is that unlike with protection of adults, where protection is separately mentioned only with regard to women, ${ }^{59}$ there is no gender or sex-specific notion with regard to children. This seems to suggest that it was recognised that both girls and boys are at risk of sexual violence in armed conflict, while the question of sexual violence specifically against adult men entered into discussion only later. ${ }^{60}$ On the other hand, the Second Additional Protocol relative to non-international armed conflicts, which was drafted at the same time, does not refer to sexual violence against children generally. It only provides that 'outrages upon personal dignity, in particular humiliating and degrading treatment, rape, enforced prostitution and any form of indecent assault' against all persons who do not take or no longer take direct part in hostilities are prohibited. ${ }^{61}$ Despite this, the special protection of children from sexual violence also in non-international armed conflict is today considered to be a norm of customary international humanitarian law. ${ }^{62}$

In conclusion, while the protection of children in armed conflict in general was recognised in international law and in international humanitarian law for a longer time, the provisions protecting children from sexual violence are rather recent. International humanitarian law of the present-day evidently pays particular attention towards protecting children from sexual violence.

\section{Sexual Violence Against Children As a War Crime}

As has been presented above, despite the rules protecting children from sexual violence, sexual violence against children in armed conflict has been prevalent in armed conflicts around the world. In what follows, I will investigate the ways in which sexual violence against children has been treated as a war crime - as a serious violation or grave breach of international humanitarian law - in international criminal courts and tribunals. I will first shortly review how sexual violence gained the

\footnotetext{
${ }^{55}$ AP I (n 8) art 76(1).

56 ibid art 77(1).

${ }^{57}$ Pilloud and others (n 8)

58 ibid 900.

${ }^{59}$ AP I (n 8) art 76(1). Today it is considered that international humanitarian law protects all genders from sexual violence. See e.g. International Criminal Court, Elements of Crimes, art 8(2)(b)(xxii)-1.

${ }^{60}$ For sexual violence against men in armed conflict, see Sandesh Sivakumaran, 'Sexual Violence Against Men in Armed Conflict' [2007] 18 EJIL < http://ejil.org/pdfs/18/2/224.pdf >.

${ }^{61}$ AP II (n 8) art 4(2)(e).

${ }^{62}$ Jean-Marie Henckaerts and Louise Doswald-Beck, Customary International Humanitarian Law. Volume 1: Rules (CUP 2005) 481.
} 
status of war crime in international law and then move on to discuss how international courts and tribunals have treated sexual violence against children as a war crime.

\subsection{Sexual Violence as a War Crime - The Development}

Traditionally, sexual violence has not been at the centre focus of international criminal law. ${ }^{63}$ While both the Nuremberg Tribunal and the Tokyo Tribunal could have prosecuted rape under crimes against humanity ${ }^{64}$ they 'virtually ignored' sexual violence in their judgments. ${ }^{65}$ The Tokyo Tribunal did nevertheless briefly discuss the Rape of Nanking, and in this context it was noted that '[e]ven girls of tender years [...] were raped in large numbers.' ${ }^{66}$ After the Second World War, despite the increased attention on sexual violence in the Conventions, neither the Geneva Conventions ${ }^{67}$ nor the Additional Protocols ${ }^{68}$ listed sexual violence as a grave breach or serious violation of international humanitarian law.

As sexual violence in armed conflict became topical in the 1990s, several influential bodies started to express views that it should be considered a war crime, regardless of the fact that the Conventions did not specifically criminalise it. It was considered that sexual violence was covered under the grave breach of 'wilfully causing great suffering or serious injury to body or health' and under customary law. ${ }^{69}$ When the international criminal tribunals were established to prosecute alleged crimes that had occurred during the armed conflicts in the former Yugoslavia and in Rwanda, influential feminist legal scholars and practitioners worked hard to ensure that sexual violence would finally be prosecuted on international level. ${ }^{70}$ Rape was then listed as a crime against humanity in both ICTY and ICTR Statutes but other forms of sexual violence were not explicitly included nor was rape as a war crime. Despite this, the Tribunals started to prosecute rape and other forms of sexual violence as a war crime early on.

In Akayesu, the first case including charges of sexual violence in the ICTR, the Prosecutor included rape as an outrage upon personal dignity under violation of Common Article 3 of the Geneva

\footnotetext{
${ }^{63}$ Rhonda Copelon, 'Gender Crimes as War Crimes: Integrating Crimes against Women into International Criminal Law' [2000] 46 McGill LJ 217, 220.

${ }^{64}$ Agreement for the Prosecution and Punishment of the Major War Criminals of the European Axis Powers and Charter of the International Military Tribunal (entered into 8 August 1945) 82 UNTS 279 art 6(c); Charter of the International Military Tribunal for the Far East (Tokyo IMT Charter) (entered into 16 January 1946) UN Doc A/CN.4/5 art 5(c).

${ }^{65}$ Theodor Meron, 'Reflections on the Prosecution of War Crimes by International Tribunals' [2006] 100 AJIL 551, 567.

${ }^{66}$ Judgment of the International Military Tribunal for the Far East (1948) (University Press Amsterdam 1977) 389-391.

${ }^{67} \mathrm{GC}$ I (n 42) art 50; GC III (n 42) art 130; GC IV (n 42) art 147.

${ }^{68} \mathrm{AP}$ I (n 8) art 85. The AP II does not contain provisions for grave breaches.

${ }^{69}$ International Committee of the Red Cross, 'Aide-Mémoire' (3 December 1992) cited in Meron (n 47) 426; Letter from Robert A. Bradtke, Acting Assistant Secretary for Legislative Affairs, to Senator Arlen Specter (27 January 1993) cited in Meron (n 47) 427.

${ }^{70}$ See, example, Askin (n 18) 300-303.
} 
Conventions and of Article 4(2)(e) of Additional Protocol II in the charges. However, the Trial Chamber concluded that it was not possible to prove that the rapes in question were linked to the armed conflict and hence the charges of war crime were dismissed. ${ }^{71}$ Sexual violence as a war crime reappeared in the ICTY in Furundžija. In Furundžija the Trial Chamber argued that rape can be prosecuted under violations of the laws and customs of the war ${ }^{72}$ and further stated that torture and outrages upon personal dignity, including rape, 'are prohibited under customary international law at all times. ${ }^{73}$ In its analysis of international humanitarian law, the Trial Chamber noted that '[i]t is indisputable that rape and other serious sexual assaults in armed conflict entail the criminal liability of the perpetrators ${ }^{74}$ and convicted Furundžija, ${ }^{75}$ and later Kunarac,${ }^{76}$ of rape as violations the laws and customs of war. Today, sexual violence has been prosecuted and convictions given on wilfully causing great suffering as grave breach of the Geneva Conventions, ${ }^{77}$ as well as under constituting violations of the laws or customs of war as cruel treatment, ${ }^{78}$ torture $^{79}$ and outrages upon personal dignity $^{80}$. Furthermore, the Rome Statute of the International Criminal Court unequivocally includes different forms of sexual violence as a war crime. ${ }^{81}$

The above-mentioned Kunarac case is of interest here as it also involved sexual violence against children - including a 12-year-old girl. But before going there, I will briefly consider crimes against children in international courts and tribunals.

\subsection{Children in International Criminal Courts and Tribunals}

At first glance, apart from the child soldier cases in the SCSL and the ICC, children have not been particularly visible in international courts and tribunals. The Nuremberg Tribunal, despite the evidence it had of crimes - mostly murder - committed against children, did not pay much attention

\footnotetext{
${ }^{71}$ Akayesu (n 13) [416], [421]-[422], [426].

${ }^{72}$ Statute of the International Criminal Tribunal for the Former Yugoslavia (25 May 1993) UNSC Res 827, art 3.

${ }^{73}$ Prosecutor v Anto Furundžija (Decision on the Defendant's Motion to Dismiss Counts 13 and 14 of the indictment (Lack of Subject Matter Jurisdiction)) ICTY-95-17/1 (29 May 1998) [13].

${ }^{74}$ Prosecutor v Anto Furundžija (Judgment) ICTY-95-17/1-T (10 December 1998) ('Furundžija Trial Judgment') [186]. That both rape and other forms of sexual violence constitute war crimes has later been confirmed. See, example, Prosecutor v Prlić et al (Judgment) ICTY-04-74-T (29 May 2013) [116].

75 ibid [274].

${ }^{76}$ Prosecutor v Dragoljub Kunarac et al (Judgment) ICTY-96-23-T \& IT-96-23/1-T (22 February 2001) ('Kunarac et al Trial Judgment') [883], [886], [888]. See also Michelle Jarvis, ‘An Emerging Gender Perspective on International Crimes' in Gideon Boas and William A Schabas, International Criminal Law Developments in the Case Law of the ICTY (Martinus Nijhoff Publishers 2003) 171.

77 ibid.

78 ibid.

${ }^{79}$ Furundžija Trial Judgment (n 74) Kunarac et al Trial Judgment (n 76).

${ }^{80}$ Furundžija Trial Judgment (n 74).

${ }^{81}$ Rome Statute (n 15) arts 8(2)(b)(xxii); 8(2)(e)(vi).
} 
to these crimes, but treated children together with the cases involving men and women. ${ }^{82}$ As seen above, the Tokyo Tribunal did sometimes mention children, but mostly followed a similar practice as the Nuremberg Tribunal. ${ }^{83}$ While the practice of the modern international criminal courts and tribunals varies - and is analysed in detail below - the statutes of the courts and tribunals do not deal separately with crimes against children. This approach is then different from that of national criminal laws, which were referred to earlier. Indeed, apart from the crime of conscripting, enlisting and using children to actively participate in hostilities, ${ }^{84}$ none of the statutes of the contemporary international criminal courts and tribunals include child-specific crimes. The SCSL does list abuse of girls up to 14 years of age in its Statute, but it is listed under crimes under Sierra Leonean law, not as an international crime. ${ }^{85}$

In the light of the above background I will now consider whether the international courts and tribunals have reflected the special protected status of children under international humanitarian law. I will ask, do the courts and tribunals pay particular attention to the protection of children under international humanitarian law when they are dealing with child victims of war crime of sexual violence? I will start with the case law of the ICTY, ICTR and SCSL and I will then move on to look at the current developments at the ICC.

\subsubsection{Finding the Child Victims}

I will start my analysis by considering whether violence against children was made clearly visible through the case law of the courts and tribunals. One would assume that it would be easy to give an affirmative answer, as the ICTY, ICTR and SCSL all dealt with several cases which involved sexual violence against children. Despite this, finding the child victims in the case law can indeed be somewhat challenging as children are mixed in the same cases with adults. This is apparent both in the documents of the Prosecution and in those of the Chambers. Yet, at times attention seems to be directed specifically at children. An example of the practice are the Kunarac and Brđanin cases at the ICTY. The practice of both the Prosecutor and the Chambers varied in the cases. In the Brđanin indictment, the Prosecutor did not mention the child victims at all, ${ }^{86}$ whereas in the Kunarac indictment the Prosecutor identified several child victims of sexual violence, systematically noting

\footnotetext{
${ }^{82}$ See Judgment of the Nuremberg International Military Tribunal 1946 (1947) 41 AJIL 172 [455], [462], [463], [466], [484], [546].

${ }^{83}$ Judgment of the International Military Tribunal for the Far East (n 66) 388, 389, 399.

${ }^{84}$ Rome Statute (n 15) arts 8(2)(b)(xxvi) and 8(2)(e)(vii).

${ }^{85}$ Statute of the Special Court for Sierra Leone, UNSC Res 1315 (16 January 2002) art 5(a).

${ }^{86}$ Prosecutor v Radoslav Brđanin (Sixth Amended Indictment) ICTY-99-36-T (9 December 2003).
} 
their ages. ${ }^{87}$ In the judgements the Tribunal sometimes referred to girls specifically by their age, but it also equally often mixed them with adults. For example, sometimes the judgements refer to 'girls' or 'high school girls', or even their age is mentioned, as is in the case of A.B., a 12-year-old girl. ${ }^{88}$ However, the same victim A.B. is referred to as a 'woman' in other parts of the judgment, ${ }^{89}$ as are 13- and 16-year-old girls in Brđanin. ${ }^{90}$ Further, as groups of victims are occasionally referred to as 'women and girls' and sometimes just as women, it is impossible to know whether this is intentional and the crimes were only committed against the adults, or if the girls were also involved. ${ }^{91}$ Neither does the ICTY note that children enjoy special protection under international humanitarian law in connection to these cases - even if the fact that the victims were children may affect sentencing, as is seen below.

Sexual violence was mostly prosecuted either as an act constituting genocide or as a crime against humanity in the ICTR. Cases including sexual violence as a war crime are few. Similar to the ICTY, the ICTR does not explicitly note that the victims were children and uses terms confusingly, which leaves much to guessing - or at least requires detective work from the reader. While the Tribunal uses expressions such as 'young girl', they are not limited to children, but are also used for young adults. ${ }^{92}$ Renzaho is the only case in which the accused was convicted on trial of a war crime of a rape of a person who clearly was a minor: the case concerned a 14-year-old Tutsi girl who had repeatedly been raped by the Interahamwe militia. ${ }^{93}$ This was despite the fact that his indictment did not mention child victims in relation to sexual violence. ${ }^{94}$ However, his conviction was later overturned on appeal due to procedural matters. ${ }^{95}$ In Bagosora, the Trial Chamber refers to 'a girl' and 'young women', but the only time it directly refers to a 13-year-old girl, it notes that the rape of the girl could not be connected to the accused. ${ }^{96}$

\footnotetext{
87 Prosecutor $v$ Dragoljub Kunarac et al (Third Amended Indictment (Kunarac and Kovač)) ICTY-96-23-PT (8 November 1999) [1.7], [11.1].

${ }^{88}$ Kunarac et al Trial Judgment (n 75) [42], [56], [63], [587], [670], [749], [754], [758]; For other similar cases see, example, Prlić et al Trial Judgment (n 73) [775]; Prosecutor v Mico Stanišić and Stojan Župljanin (Judgment) ICTY-0891-T (27 March 2013) [603], [633], [682]; Prosecutor v Dragan Zelenović (Judgment) ICTY-96-23/2-S (4 April 2007) [22], [23].

${ }^{89}$ Kunarac et al. Trial Judgment (n 75) [42].

${ }^{90}$ Prosecutor v Radoslav Brđanin (Judgment) ICTY-99-36-T (1 September 2004) [514], [518].

91 ibid.

92 Prosecutor $v$ Ndindilyimana et al (Judgment) ICTR-00-56-T (17 May 2011) [1053]. See also, Prosecutor $v$ Nyiramasuhuko et al (Judgment) ICTR-98-42-T (24 June 2011) [3129], [3132], [3135].

${ }_{93}$ Prosecutor $v$ Tharcisse Renzaho (Judgment) ICTR-97-31 (14 July 2009) [687], [689].

${ }^{94}$ Prosecutor $v$ Tharcisse Renzaho (Second Amended Indictment) ICTR-97-31-I (16 February 2006).

95 Prosecutor v Tharcisse Renzaho (Appeal Judgment) ICTR-97-31-A (1 April 2011) [129], [622].

${ }^{96}$ Prosecutor $v$ Théoneste Bagosora et al (Judgment) ICTR-98-41-T (18 December 2008) [2253]; Prosecutor v Théoneste Bagosora et al (Amended Indictment Théoneste Bagosora) ICTR-96-7-I (12 August 1999) [5.45], [6.59], [6.65].
} 
In the SCSL, crimes against child soldiers were a consistent element throughout the proceedings. This shows how children are consistently more visible in case law regarding sexual violence crimes. Notwithstanding, some vagueness remains. While in all SCSL cases the prosecution mentioned both 'women' and 'girls' whenever it referred to sexual violence, it did not, however, make reference to how the presence of children as victims would affect the case. ${ }^{97}$ In the $R U F$ judgement, the SCSL often referred to the age of the victim in relation to a 'girl' and used the term only for those between 10 and 18 year's old ${ }^{98}$ thus clearly recognising that some of the victims were children. However, it also used terms 'women and girls' and 'women' interchangeably, which leaves the reader again guessing whether the crimes were actually committed against children as well. An example of this is a situation in which both 'women and girls' were abducted and later 'some women' were raped. 99 Furthermore, in Taylor, the Court is more inconsistent and, for example, does not differentiate between 13 and 20 year-old 'girls.' ${ }^{100}$ In the AFRC some victims of sexual violence have specified

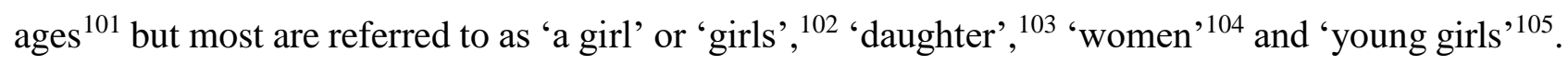

The above practise of the three courts suggests that while the courts did occasionally note that cases involving children were specific, neither the Prosecution nor the Chambers seemed to have a clear strategy for handling sexual crimes against children. Instead, they seem to mostly disappear into the vast quantity of crimes and leaves the reader guessing, whether all or even most child victims were even referred to as children. Some of the obscurity may be a result of the reality of international criminal proceedings: giving evidence might take place a long time after the actual events, and witnesses may be not only traumatised but also unable to remember details. Yet, the fact that the courts never explicitly state that they were unable to ascertain the age of the victim suggests that perhaps they did not consider it to be a primary issue. Of course, as the Prosecutor did not charge specific crimes against children, the judgements can neither include such. However, in cases in which children were brought up, the logic still varied throughout the system: children appear in the judgements of cases in which they are not mentioned in the indictments and sometimes they are lost after the indictment. The SCSL was somewhat an exception of the rule at times, as it did notice children. This does not mean, however, that there would have been a clear and consistent practice.

\footnotetext{
${ }^{97}$ See, example, Prosecutor v Augustine Gbao (Indictment) SCSL-2003-09-I-009 (16 April 2003) [31]-[32], [40]-[44]; Prosecutor v Alex Tamba Brima (Indictment) SCSL-2003-06-I (7 March 2003) [29]-[30], [38]-[42].

${ }^{98}$ RUF Trial Judgment (n 18) [1178], [1407], [1409], [1520], [1562], [1622].

99 ibid [1154].

${ }^{100}$ See, example, Taylor Trial Judgment, supra note 27 [880], [901], [938], [945], [958], [981], [987], [990].

${ }^{101}$ AFRC Trial Judgment (n 29) [975], [1153], [1175].

102 ibid [1022], [1164].

103 ibid [1036].

104 ibid [1141], [1455]-[1456].

105 ibid [1162].
} 
All this seems to imply that the courts did not pay attention in their case law to the particularly protected position of children in international humanitarian law.

\subsubsection{Does It Make the Crime Graver If Victims Are Children?}

The ICTY, ICTR and SCSL have in their case law concerning sexual violence considered that the involvement of children is an aggravating factor or affects the gravity of the crimes - even if he practice has not been consistent. ${ }^{106}$ The ICTY was rather coherent on this matter: when the Tribunal did recognise sexual violence against children, it regularly considered the fact that because the victims were children, this constituted either an aggravating circumstance, or a factor affecting the gravity of the crime. For example, in Zelenović, the Trial Chamber noted that the victim 'was about 15 years old at the time of the commission of the crimes. This further increases the gravity of the crimes committed against her.' 107

Unlike the ICTY, the ICTR was not as consistent in its approach. The Trial Chamber noted only in Nyiramasuhuko et al. that many of the victims being 'particularly vulnerable' was an aggravating factor. ${ }^{108}$ It did not elaborate, however, what 'vulnerability' meant nor did it establish the ages of the victims. The only case in which the ICTR explicitly referred to the young age of the victim as an aggravating factor was in Muhimana, but this was done in relation to genocide and crimes against humanity. ${ }^{109}$ The SCSL followed a similar practice. In AFRC, the Trial Chamber considered that because the victims included young girls subjected to sexual violence, it was either an aggravating circumstance or factor affecting the gravity of the crime. ${ }^{110}$ However, in $R U F$, the Trial Chamber did not include the vulnerability of children as a factor affecting the gravity of the crime, even after it recognised that child victims were particularly vulnerable. ${ }^{111}$ This is interesting because the Prosecutor emphasised in their Sentencing Brief that the vulnerability of child victims should affect the gravity of the crimes. ${ }^{112}$ Finally, in Taylor, the Trial Chamber once again mentioned age as an

\footnotetext{
${ }^{106}$ Prosecutor v Mikaeli Muhimana (Judgment and Sentence) ICTR-95-1B-T (28 April 2005) [607]; ('Muhimana Trial Judgement'); Kunarac et al Trial Judgment (n 75) [864], Prosecutor v Kunarac et al (Appeal Judgment) ICTY-96-23\&IT96-23/1-A (12 June 2002) [355]; Prosecutor v Miroslav Bralo (Sentencing Judgment) ICTY-95-17-S (7 December 2005) [26]-[27], [31]; Prosecutor v Dragan Zelevonić (Sentencing Judgment) ICTY-96-23/2-S (4 April 2007) [39]; Prosecutor $v$ Alex Tamba Brima et al (AFRC) (Sentencing Judgment) SCSL-04-16-T (19 July 2007) ('AFRC Sentencing Judgment') [55], [85], [109].

${ }^{107}$ Zelenović Trial Judgment (n 87) [39] (emphasis added). See also, Prlić et al. Trial Judgment (n 73) [1305] and Stanišić and Župljanin Trial Judgment (n 87) [927], [946]. Findings of sexual violence as an aggravating factor were done in Kunarac et al Trial Judgment (n 75) [864], [874], [879]; Brđanin Trial Judgment (n 89) [1106], the Appeals Chamber however overturned the part related to rapes in camps as torture on the basis of insufficient evidence.

${ }^{108}$ Nyiramasuhuko et al. Trial Judgment (n 91) [6208].

${ }^{109}$ Muhimana Trial Judgement (n 105) [607].

${ }^{110}$ AFRC Sentencing Judgment (n 106) [55], [75], [85], [109].

${ }^{111}$ Prosecutor v Issa Hassan Sesay et al (RUF) (Sentencing Judgment) SCSL-04-15-T (8 April 2009) [128].

112 Prosecutor v Issa Hassan Sesay et al (RUF) (Prosecution Sentencing Brief) SCSL-04-15-T (10 March 2009) [108][111].
} 
aggravating factor in general, ${ }^{113}$ but did not clearly explain in the judgment whether it had been counted as such in the case.

As can be seen, international courts and tribunals have in many cases considered that if a victim of sexual violence is a child, this makes the crime graver or is an aggravating factor. While the courts and tribunals have not opened the reasoning behind this - apart from noting that children are vulnerable victims - this seems to follow from the same logic as that of national legislations, which usually provide longer sentences if the crime is committed against a child. The difference is that in many national legislations a sexual crime against a child is seen as a separate crime, whereas on international level the issue has been considered only at the sentencing stage.

Despite the fact that attention has been paid to children in this sector, the varying and inconsistent practice suggests that the courts and tribunals have not yet developed a coherent strategy in their sentencing approach for crimes against children. The examples of the case law presented above are rather confusing for the reader. This is further complicated by the fact that the courts and tribunals do not give detailed arguments on how age was a relevant (or irrelevant) factor affecting the gravity of the crime, or how it was considered to be an aggravating factor. Thus, the reasoning remains in the dark, and in practice, has resulted in a fragmented approach to sentencing. As was seen above, the preferred approach may follow from national practice that often considers sexual crimes against children as particularly grave, but this cannot be said with surety. Additionally, present practice is somewhat contradictory considering the inconsistent identification of child victims in the case law. If the fact that the victim was a child was considered important in sentencing, why did the courts and tribunals not systematically aim at identifying them? The image the case law of the ICTY, ICTR and SCSL leaves is that the fact that the victims were children was not systematically considered by the institutions. At present, it appears that the consideration of child victims was merely incidental to the decision-makers approach to sentencing.

\subsubsection{International Criminal Court}

When the ICC was being established, it seemed that it would have a specific interest in crimes committed against children. Already at the early stages of the Rome Conference, a number of States expressed their concern in sexual violence against children in armed conflict and noted that it should be included in the crimes of the Rome Statute. Finland noted that '[i]n defining war crimes and crimes against humanity, the conference must bear in mind the increasing vulnerability of women and

${ }^{113}$ The Prosecutor v Charles Ghankay Taylor (Sentencing Judgment) SCSL-03-01-T (30 May 2012) [25]. 
children to exploitation and sexual violence in armed conflicts'. ${ }^{114}$ Israel endorsed the view that 'gender crimes and crimes against children' should be included in war crimes. ${ }^{115}$ Mexico also seemed to support the notion that sexual violence against children should be a war crime as it noted that crimes against women and children, and especially sexual assaults should be included in the crimes under the Courts jurisdiction. ${ }^{116}$ Uganda - having first-hand experience in a brutal armed conflict voiced its concern strongly and noted that ' $[\mathrm{t}]$ he prosecution of abduction, rape, enslavement, and other forms of child abuse should be prominently reflected in the Statute. ${ }^{117}$ Additional States expressed their concern for children, even if they did not clearly indicate whether those crimes should be included under crimes against humanity or war crimes. ${ }^{118}$ Similar views were also expressed by organisations present at the Conference. ${ }^{119}$ It seems that some States would have wished that violence against children had been emphasised more in the Statute, and that perhaps separate crimes of violence against children in addition to that of recruitment and use of child soldiers be included either in the Statute in general or under war crimes in particular. Yet, as the final Rome Statute shows, this is not the case today. A special concern for children is nevertheless reflected in the Statute, as it provides that the staff of the Court, including Judges and the Prosecutor's Office, must include persons with expertise on violence against children. ${ }^{120}$ Further, the Elements of Crimes of the ICC note that children are particularly vulnerable to trafficking in the context of sexual slavery. ${ }^{121}$ The special concern for children is also reflected in the Office of the Prosecutor's Policy on Children. In the Policy, the Office of the Prosecutor raises crimes against children as one of its main concerns, and recognises sexual violence as a crime specifically affecting children. As already referred to in the introduction, the Policy further notes that following the special protection of children under international law, crimes against children will be regarded as 'particularly grave. ${ }^{\text {, }} 22$

Several of the first cases of the ICC have included crimes against children. The first judgment to come out, the Lubanga case, ${ }^{123}$ concentrated solely on the recruitment and use of children in armed conflict

\footnotetext{
114 'Official Records, Volume II, Summary records of the plenary meetings and of the meetings of the Committee of the Whole' UN Diplomatic Conference of Plenipotentiaries on the Establishment of an International Criminal Court (United Nations, 17 July 1998) < http://legal.un.org/icc/rome/proceedings/E/Rome\%20Proceedings_v2_e.pdf> ('Rome Conference Records') 98.

115 ibid 99.

116 ibid 107.

117 ibid 118, 276.

118 ibid; with regard to Italy 62, 125; Trinidad \& Tobago 66; Canada, 68; Slovenia, 70; Dominican Republic, 285. See also, Costa Rica, 77; Andorra, 81; Samoa, 109; India, 168; Australia, 235.

119 ibid with regard to UNICEF, 112, Children's Caucus International, 72.

${ }^{120}$ Rome Statute (n 15) arts 36(8)(b), 42(9).

${ }^{121}$ Elements of Crimes (n 58) arts 8(2)(b)(xxii), 8(2)(e)(vi).

${ }^{122}$ ICC (n 6) 8, 24, 26.

${ }^{123}$ Prosecutor $v$ Thomas Lubanga Dyilo (Judgment on the Appeal of Mr Thomas Lubanga Dyilo against His Conviction) ICC-01/04-01/06 A 5 (1 December 2014).
} 
situations. The concentration on child soldiers opened the ICC for the criticism of not having paid attention to sexual violence against girls when there was evidence suggesting that such crimes had taken place. ${ }^{124}$ After Lubanga, attention was directed to the cases against Germain Katanga and JeanPierre Bemba. They both were accused of sexual violence and Bemba's case included also sexual violence against children. Katanga was acquitted of sexual violence charges on the basis that responsibility of the accused for the crimes alleged could not be established. ${ }^{125}$ Bemba was convicted of rape as a war crime - including rape against children - by the Trial Chamber. ${ }^{126}$ This outcome was short-lived though, as Bemba was acquitted of all charges on appeal. The Appeals Chamber found that Trial Chamber had erred in convicting Bemba of acts that were not included in the confirmed charges and in assessing the measures Bemba had taken as a commander to prevent, repress or punish the crimes committed by his subordinates. ${ }^{127}$ Nonetheless, the argumentation in Bemba offers a first glimpse to the way in which the ICC pays attention to the special protection of children from sexual violence in armed conflict.

With regard to defining children, the ICC Trial Chamber in Bemba seemed to pay more attention to war crimes committed against children than its predecessors. The Trial Chamber did not make generalisations such as 'women and girls' or 'girls' but went through each victim and noted the age of each of the under-aged rape victims. ${ }^{128}$ Furthermore, when considering aggravating circumstances, the Trial Chamber did a detailed analysis on the ages of the young victims of sexual violence noting that their young age 'rendered them especially vulnerable and defenceless' which constituted an aggravating circumstance. ${ }^{129}$

Finally, a crucial case with regard to the treatment of child-related questions in the ICC is the recent Ntaganda Trial Judgment. In Ntaganda, a major issue was the recruitment and use of child soldiers as well as sexual violence against child soldiers and civilian children more generally. Ntaganda was convicted of rape and sexual slavery for both counts. In the Judgment, the Court carefully paid attention to child victims under 15 years of age and referred to the age of each victim separately. ${ }^{130}$

\footnotetext{
124 See, example, Joe Tan, 'Sexual Violence Against Children on the Battlefield as a Crime of Using Child Soliders: Square Pegs in Round Holes and Missed Opportunities in Lubanga' in Terry Gill and others (eds), Yearbook of International Humanitarian Law (TMC Asser Press 2012) 145-147.

${ }^{125}$ Prosecutor v Germain Katanga (Judgment pursuant to article 74 of the Statute) ICC-01/04-01/07 (7 March 2014).

${ }^{126}$ Prosecutor v Jean-Pierre Bemba Gombo (Judgment pursuant to Article 74 of the Statute) ICC 01/05-01/08 (21 March 2016) ('Bemba Trial Judgment').

${ }^{127}$ Prosecutor v Jean-Pierre Bemba Gombo (Judgment on the appeal of Mr Jean-Pierre Bemba Gombo against Trial Chamber III's “Judgment pursuant to Article 74 of the Statute”) ICC-01/05-01/08 A (8 June 2018) [4], [115]-[116], [194].

${ }^{128}$ Bemba Trial Judgment (n 125) [467], [469], [489], [493], [511], [516].

${ }^{129}$ Prosecutor v Jean-Pierre Bemba Gombo (Sentencing Judgment, "Decision on Sentence pursuant to Article 76 of the Statute") ICC-01/05-01/08 (21 June 2016) [42]-[43].

${ }^{130}$ Ntaganda Judgment (n 2) [89], [151], [174], [406]-[413].
} 
It is likely that this was partly because many of the cases were related to child recruitment - in which case establishing age is crucial. The Court also paid attention to age in the case of civilian victims. ${ }^{131}$ This suggests that the Court considered that child victims - irrespective of their role - required particular attention. The Court also emphasised the vulnerability of the young victims in several occasions. ${ }^{132}$ However, as at the time of the writing, how and if this will affect Ntaganda's sentencing is unknown since Bosco Ntaganda has yet to receive his sentence. Nevertheless, this case demonstrates how sexual violence against children often overlaps with recruitment and the use of children in armed conflict, as child soldiers often face sexual violence in military. As the cases suggest, the ICC is improving in identifying children amongst the victims and in paying attention to the war crimes committed against them. Similarly, the policy of the Office of the Prosecutor shows a determination to tackle crimes against children. However, the early failures of the ICC seem to suggest that sexual crimes - even if committed against children - were not originally on the priority list of the Prosecution. Sexual violence involving girl victims is also in the list of the charges in several upcoming ICC cases. ${ }^{133}$ It remains to be seen how children are taken into account in these cases. None of the cases on Pre-Trial stage at the ICC specifically define boys as victims of sexual violence at the time of the writing.

\section{Concluding Remarks}

Protection of children in armed conflict is a prominent feature of international humanitarian law and protection of children from sexual violence in armed conflict has been part of the treaty regime for more than four decades. This emphasis and special protection has however not been consistently reflected in the case law of international courts and tribunals on sexual violence against children as a war crime. Even the partial successes and the seemingly increased attention of the ICC cannot be considered to have created a coherent policy of paying particular attention to war crimes committed against children. The case law of the courts and tribunals strongly reflects the interests of the time. While sexual violence may not have been a point of interest when the international tribunals for the former Yugoslavia and Rwanda were established, ${ }^{134}$ it soon became so and the attention - thanks to

\footnotetext{
${ }^{131}$ Ntaganda Judgment (n 2) [519], [521], [579]. The Court referred only to 'girl' in [523].

${ }^{132}$ Ntaganda Judgment (n 2) [792], [818].

133 The cases listed here include only those that explicitly mention sexual violence against children. Prosecutor $v$ Al Hassan Ag Abdoul Aziz Ag Mohamed Ag Mahmoud (Arrest Warrant) ICC-01/12-01/18 (27 March 2018) [9]; Prosecutor $v$ Ahmad Harun (Warrant of Arrest for Ahmad Harun) ICC-02/05-01/07 (27 April 2007) [13]; Prosecutor v Abdel Raheem Muhammad Hussein (Warrant of Arrest for Abdel Raheem Muhammad Hussein) ICC-02/05-01/12 (1 March 2012) [9]; Prosecutor v Joseph Kony et al. (Amended Warrant of Arrest for Joseph Kony) ICC-02/04-01/05 (27 September 2005) [5]; Prosecutor v. Dominic Ongwen (Decision on the confirmation of charges against Dominic Ongwen, Public Redacted Version) ICC-02/04-01/15 (23 March 2016) [109], [116], [137].

${ }^{134}$ Michelle Jarvis and Kate Vigneswaran, 'Challenges to Successful Outcomes in Sexual Violence Cases' in Serge Brammertz and Michelle Jarvis (eds), Prosecuting Conflict-Related Sexual Violence at the ICTY (OUP 2016) 36-37.
} 
the strong work of feminist lawyers - was on women as victims of sexual violence. There was no similar attention to child victims, which is then reflected in the case law. Following the civil war in Sierra Leone there was increased recognition of crimes against children, which can also be seen in the case law, even if mostly on child soldiers. Similarly, the ICC has on many occasions stressed its specific emphasis on atrocities against children, ${ }^{135}$ and this has also been reflected in its case law. The ICC has also paid attention to sexual violence against child soldiers, particularly in the Ntaganda case, as seen above, which is interesting, as it is an issue that is rather invisible in the Geneva Conventions.

While the ICC seems to be starting to pay special attention to sexual violence against children, the case law of the international courts and tribunals generally does not reflect the attention to protection of children in international humanitarian law. Further, as noted by the ICTY prosecutors, even if the ICTY judgments include several cases of sexual violence against girls, they do not reflect the reality of the armed conflict, which reportedly included instances of sexual violence against children as young as seven years old. ${ }^{136}$ Indeed, perpetrators of crimes against children still rarely end up in courts. ${ }^{137}$ An interesting fact is also that despite the knowledge of boys as victims of sexual violence, there is not one case of sexual violence against boys. ${ }^{138}$ This indicates that sexual violence against boys as a war crime - or as crime against humanity for that matter - is still very much lost in case law.

Having established that there has been a discrepancy between the provisions of international humanitarian law and the practise of international courts and tribunals, and that the discrepancy may be decreasing following the recent practise of the ICC, the last question to ask is, why does this discrepancy matter? First, recognising child victims during the proceedings would be important for the question of sentencing: the sporadic practice with sentencing has created incoherence - and possibly inequality for both victims and defendants - in the practise of the courts and tribunals. I do not, however, argue that sexual violence against children should necessarily be seen as a separate crime. It could be possible to argue, along similar lines as the SCSL did in Norman with regard to use

\footnotetext{
135 See, example, ICC (n 6).

${ }^{136}$ Saeeda Verrall, 'The Picture of Sexual Violence in the Former Yugoslavia Conflicts as Reflected in ICTY Judgments' in Serge Brammertz and Michelle Jarvis (eds), Prosecuting Conflict-Related Sexual Violence at the ICTY (OUP 2016) 312. See also UNSC, 'Letter Dated 24 May 1994 from the Secretary-General to the President of the Security Council Addendum: Annexes to the Final Report of the Commission of Experts' (27 May 1994) UN Doc S/1994/674 [210]-[211]. ${ }^{137}$ UNICEF Innocenti Research Centre (n 15) 29.

138 The charges in Bemba mentioned sexual violence against boys. Prosecutor v Jean Pierre Bemba Gombo (Public Redacted Version of the Amended Document Containing the Charges) ICC-01/05-01/08 (30 March 2009) [39].
} 
and recruitment of child soldiers, ${ }^{139}$ that sexual violence against children is a crime based on customary law. It could also be suggested that the crime of sexual violence against children should be added to the Rome Statute - yet, it is a further question whether this would be feasible in practice. Instead, it is important to ensure that the child victims are visible in the case law, and to follow a uniform practice with regard to sentencing to apply equal treatment and accountability for sexual violence committed against children in armed conflict. Indeed, by paying attention to child victims amid the mass of crimes, the international criminal courts and tribunals could respond to the calls for enhanced accountability for sexual violence committed against children in armed conflict. ${ }^{140}$ It would be a concrete measure to bring to the forefront the violence against children who often suffer most from the consequences of war, as well as reflect the special protection of children in international humanitarian law as emphasised by the ICC's Prosecutor. Nonetheless, it should be noted when particular attention is paid to a specific group, there is a risk that those who do not belong to that group - in this case adult and possibly adolescent women and men - are forgotten. Therefore, should sexual violence against children receive more attention in the future, careful attention must be given so that sexual violence against those who are not children is not side-lined either.

\footnotetext{
${ }^{139}$ Prosecutor v Sam Hinga Norman (Decision on Preliminary Motion Based on Lack of Jurisdiction (Child Recruitment), SCSL-2004-14-AR72(E) (31 May 2004).

${ }^{140}$ For a resent call for better accountability, see e.g. Shaheed and others, Protecting Children in Armed Conflict (Hart Publishing 2018) 285.
} 